\title{
A Systematic Review of Patient-reported Outcome Measures Used in Circular Frame Fixation
}

\author{
Tony Antonios ${ }^{1}$, Amy Barker ${ }^{2}$, Inji Ibrahim ${ }^{3}$, Christine Scarsbrook ${ }^{4}$, Peter J Smitham ${ }^{5}$, W David Goodier ${ }^{6}$, Peter R Calder ${ }^{7}$
}

\begin{abstract}
Introduction: Clinical studies in orthopedics are using patient-reported outcome measures (PROMs) increasingly. PROMs are often being designed for a specific disease or an area of the body with the aim of being patient centered. As yet, none exists specifically for treatment with circular ring external fixation devices.

Aim: The purpose of this study is to provide a comprehensive systematic review of the published literature related to the use of PROMs in patients that underwent treatment with circular frames (Ilizarov or Hexapod Type Fixators).

Methods: An online literature search was conducted for English language articles using the Scopus.

Results: There were 534 published articles identified. After initial filtering for relevance and duplication, this figure reduced to 17, with no further articles identified through searching the bibliographies. Exclusion criteria removed two articles resulting in 15 articles included in the final review. Out of the 15 studies identified, a total of 10 different scoring measures where used. The majority of studies used a combination of joint/limb-specific and generic health PROMs with an average of 2.5 per study. No paper specifically discussed all eight PROMs criteria when justifying which PROMs they used.

Conclusion: Our findings indicate that none of the PROMs analyzed in this systematic review are truly representative of the health outcomes specific to this patient group and, therefore, propose that a PROM specific to this patient group needs to be developed.

Keywords: Hexapod type fixators, llizarov, Outcome measures, PROMs, Systematic review.

Strategies in Trauma and Limb Reconstruction (2019): 10.5005/jp-journals-10080-1413
\end{abstract}

\section{INTRODUCTION}

Circular external fixation devices are used in the treatment of complex fractures, to address bone defects and correct deformities. The frames are large, cumbersome, and are in place for a number of months, with patients experiencing unique health and quality of life (QoL) problems during this period. A PROM that records this impact and is specific to this patient group would be useful but none, as yet, exists.

PROMs measure the quality of health from a patient's perspective; a written questionnaire that the patient completes in their own time is the basis for a quantifiable and standardized score which can then be used to measure health quality.

The importance of this was highlighted as early as 1999 by a Symposium published in the Journal of Bone and Joint Surgery. ${ }^{1}$ The vital role of PROMs in delivering a patient-centered evaluation of the quality of care is being recognized increasingly and not least by the UK Department of Health (DoH) which made it a requirement for all NHS providers to collect PROMs data about certain interventions from April 2009. The aim of this is to support evaluations by clinicians, managers, regulators, commissioners, and patients of the relative clinical quality and performance of providers of relevant elective procedures. ${ }^{2}$ The $\mathrm{DoH}$ has recognized that there is a need to roll out this type of evaluation to other health care services. ${ }^{3}$

There is a greater need for PROMs when circular frames are used for patients who are motivated to undertake a procedure for reasons that are not entirely clinical in nature; e.g., cosmesis and social functioning as in limb lengthening for stature increase. There may not be improved functional outcomes after limb lengthening but measurable improvements in the QoL are seen. ${ }^{4}$

Treatment using the llizarov device can be for several months. ${ }^{5}$ This can have profound short-term health and QoL
'Department of Trauma and Orthopaedics, King's College Hospital NHS Foundation Trust, London, UK

${ }^{2-4}$ Institute of Orthopaedics and Musculoskeletal Sciences, University College London, Royal National Orthopaedic Hospital, Brockley Hill, Stanmore, UK

${ }^{5}$ Institute of Orthopaedics and Musculoskeletal Sciences, University College London; Royal National Orthopaedic Hospital, Brockley Hill, Stanmore, UK; Department of Trauma and Orthopaedics, Royal Adelaide Hospital, Port Road, Adelaide, South Australia, Australia

${ }^{6,7}$ Royal National Orthopaedic Hospital, Brockley Hill, Stanmore, UK

Corresponding Author: Peter J Smitham, Institute of Orthopaedics and Musculoskeletal Sciences, University College London; Royal National Orthopaedic Hospital, Brockley Hill, Stanmore, UK; Department of Trauma and Orthopaedics, Royal Adelaide Hospital, Port Road, Adelaide, South Australia, Australia, Phone: +61 421622 305, e-mail: petersmitham@gmail.com

How to cite this article: Antonios T, Barker A, Ibrahim l, et al. A Systematic Review of Patient-reported Outcome Measures Used in Circular Frame Fixation. Strategies Trauma Limb Reconstr 2019;14(1):34-44.

Source of support: Nil

Conflict of interest: None

issues; it has been shown that the fixator imposes unique impacts on daily functioning. ${ }^{6}$ The risk of a negative psychological impact is indicated by studies on pediatric patients where the importance of support from the health care team in reducing such psychological impact is highlighted. ${ }^{7}$ This suggests that outcomes in this group of patients encompass a broad range of unique health and health-related quality of life (HRQoL) issues which are important measures of quality of care as well as patient outcome. 
The choice of a suitable PROMs is challenging. The specific criteria ${ }^{8}$ to be considered when selecting a PROMs include the following:

- Appropriateness: Is the instrument content appropriate to the questions which the application seeks to address?

- Acceptability: Is the instrument acceptable to patients?

- Feasibility: Is the instrument easy to administer and process?

- Interpretability: How interpretable are the scores of the instrument?

- Precision: How precise are the scores of the instrument?

- Reliability: Does the instrument produce results that are reproducible and internally consistent?

- Validity: Does the instrument measure what it claims to measure?

- Responsiveness: Does the instrument detect changes over time that matter to patients?

The purpose of this study was to provide a systematic review of the published literature on the use of PROMs in patients treated with circular frames (Ilizarov or Taylor spatial frame).

\section{Methods}

An online literature search was conducted for English language articles using the Scopus. The following search term was utilized: (TITLE-ABS-KEY (Ilizarov OR "External fixator" OR "Taylor spatial" OR "Taylor-spatial") and TITLE-ABS-KEY (score OR prom OR "patient reported outcome")). There was no set time period for the search so all articles up until 14/11/2013 were screened.

Inclusion criteria from the preliminary search:

- All original forms of study and trial design including descriptive studies such as case reports or case series, but not comments on established studies, letters to the editor, etc.

- Patient samples of only adults (16 years or older) treated with the Ilizarov or TSF external fixator in which a PROM had been used

Exclusion criteria were the following:

- Studies where all patients were uniformly treated by another procedure (e.g., Ilizarov treatment and nailing).

- Studies that did not use at least one PROM which could be applied.

Titles and abstracts of the articles produced from the search were examined for adherence to the inclusion and exclusion criteria. The bibliography and citation lists of all relevant articles were examined for further articles to be considered for inclusion. Each article included in the study was then examined for the year of publication, country of origin, type of study, number of patients, age of patients, type of PROM used, outcome measures used, and level of evidence (with justification). The results of all included studies were entered into an evidence table (Table 1).

\section{Results}

Five hundred thirty-four published articles were identified. After initial filtering for relevance and duplication, this figure reduced to 17 , with no further articles identified through searching the bibliographies. Exclusion criteria removed 2 articles (no availability of full article in English, $n=2$ ) resulting in 15 articles included in the final review (summarized in Fig. 1: the PRISMA flow diagram). A summary of all 15 articles is shown in Table 2.
No studies evaluated the PROMs according to the widely accepted techniques set out by Fitzpatrick et al. ${ }^{8}$ or the more recent consensus-based standards for the selection of health measurement instruments (COSMIN) checklist; ${ }^{9}$ however, the appropriateness, validity, responsiveness, and precision as defined earlier can be considered.

Out of the 15 studies identified, a total of 10 different scoring measures were used. The majority of studies used a combination of joint or limb-specific and generic health PROMs with an average of 2.5 per study. No paper discussed all eight PROMs criteria specifically when justifying which PROMs had been chosen. The PROM scores are discussed further below.

\section{HRQoL Measures}

\section{SF-36/SF-12}

SF-36 was the PROMs scoring system that was most commonly used in all the studies identified (studies 5, 8, 9, 10, and 15) (Table 2). Studies $5,9,13$, and 15 were prospective studies. These all showed increases between preoperative and postoperative SF-36 scores, although this pattern was not statistically significant in any of the domains in study 15 and only significant for some of the domains of studies 9 and 14 . Studies 5 and 9 both looked at scores for patients in a frame and both showed improvements compared to preoperative scores; these were only statistically significant in some domains of study 5 . This suggests that the PROM is responsive to changes in these patients but not precise in small samples (22-38 patients) such as these.

SF-36 was used in these studies to encompass a broad range of indications for the frame (2-trauma, 4-varus gonarthrosis, 8nonunion, and 10-osteoarthritis of the ankle), which suggests that the SF-36 may have a responsiveness that is reproducible between different patient subgroups prospectively.

Study 10 was a retrospective study comparing scores of SF-36 postoperatively to those of the normal control population and detected significantly lower scores in three components (physical functioning, bodily pain and emotional role) and lower scores in all others, suggesting that some items showed some responsiveness and precision to changes important to the patient and highlighting that the SF-36 can be used for retrospective studies as well. In comparison, study 8 was a retrospective study of only 22 patients and contradicted the above as it did not show a real difference in SF-36 scores between the surgical and the nonsurgical group. This could reflect the lack of difference in HRQoL scores between these groups: the nonsurgical group having untreated achondroplasia and the surgical group having complications associated with the limb lengthening procedure. However, the Rosenberg self-esteem scores (RSEM) were sensitive to changes and raises the question as to whether the SF-36 is the ideal PROM for all patient groups. The SF-36 is used widely and has been evaluated extensively. ${ }^{10,11}$ While its use in a range of relevant conditions (limb reconstruction patients, ${ }^{12}$ ankle fracture patients ${ }^{13}$ ) persists, it has been suggested that floor effects occur when used for some orthopedic conditions; this means clinically relevant changes in disability cannot be measured at low levels and, as such, the precision is limited for these conditions. ${ }^{14}$

Study 14 highlights this limitation. Despite a significant improvement at the final examination, no further significant improvement was observed at the 2-year follow-up for the physical component and the scores, in fact, remained inferior to a normal population due to persistent moderate pain and reduced mobility in many cases. Likewise, the mental component scores showed a significant improvement at the final examination with no further 
Table 1: The results of included studies stating study type, patient sample size, and level of evidence

\begin{tabular}{|c|c|c|c|c|c|}
\hline No & Ref. & Title & Type of study & Patient sample & Level of evidence \\
\hline 1 & $\begin{array}{l}\text { Barker et al. } \\
2004^{34}\end{array}$ & $\begin{array}{l}\text { Functional recovery in patients with nonunion } \\
\text { treated with the llizarov technique }\end{array}$ & $\begin{array}{l}\text { Prospective case } \\
\text { series }\end{array}$ & $\begin{array}{l}40 \text { patients } \\
32 \text { men, } 8 \text { women }\end{array}$ & Level 4 \\
\hline 2 & $\begin{array}{l}\text { Brinker and } \\
\text { O'Connor } 2007^{35}\end{array}$ & $\begin{array}{l}\text { Outcomes of tibial nonunion in older adults fol- } \\
\text { lowing treatment using the llizarov method }\end{array}$ & $\begin{array}{l}\text { Prospective case } \\
\text { series }\end{array}$ & $\begin{array}{l}23 \text { patients } \\
6 \text { lost to follow-up } \\
\text { aged } 61-92\end{array}$ & Level 4 \\
\hline 3 & $\begin{array}{l}\text { Foster et al. } \\
2012^{32}\end{array}$ & $\begin{array}{l}\text { The treatment of complex tibial shaft fractures by } \\
\text { the llizarov method }\end{array}$ & Retrospective study & $\begin{array}{l}40 \text { patients } \\
\text { Ages } 19-81 \text { (mean } 43 \text { ) } \\
28 \text { men, } 12 \text { women }\end{array}$ & Level 4 \\
\hline 4 & $\begin{array}{l}\text { Ghoneem et al. } \\
1996^{36}\end{array}$ & $\begin{array}{l}\text { The llizarov method for correction of complex } \\
\text { deformities }\end{array}$ & Retrospective review & $\begin{array}{l}45 \text { patients } \\
26 \text { boys, } 19 \text { girls } \\
\text { Aged } 3-18 \text { (mean } 12 \text { ) }\end{array}$ & Level 4 \\
\hline 5 & $\begin{array}{l}\text { Gunes et al. } \\
2008^{37}\end{array}$ & $\begin{array}{l}\text { Quality of life in patients with varus gonarthrosis } \\
\text { treated with high tibial osteotomy using the } \\
\text { circular external fixator }\end{array}$ & $\begin{array}{l}\text { Retrospective case } \\
\text { series }\end{array}$ & $\begin{array}{l}27 \text { patients } \\
\text { Aged } 45-65 \\
18 \text { females, } 9 \text { male }\end{array}$ & Level 4 \\
\hline 6 & Horn et al. $2011^{38}$ & $\begin{array}{l}\text { Supramalleolar osteotomy using circular external } \\
\text { fixation with six-axis eformity correction of the } \\
\text { distal tibia }\end{array}$ & Retrospective review & $\begin{array}{l}52 \text { patients } \\
\text { Aged 18-79 (mean 44) } \\
23 \text { men, } 29 \text { women }\end{array}$ & Level 4 \\
\hline 7 & $\begin{array}{l}\text { Robinson et al. } \\
2011^{39}\end{array}$ & $\begin{array}{l}\text { High tibial osteotomy in medial compartment } \\
\text { osteoarthris and varus deformity using the Taylor } \\
\text { spatial frame: early results }\end{array}$ & $\begin{array}{l}\text { Prospective case } \\
\text { series }\end{array}$ & $\begin{array}{l}9 \text { patients } \\
\text { Aged 37-59 (mean 49) } \\
\text { All men }\end{array}$ & Level 4 \\
\hline 8 & Kim et al. $2012^{4}$ & $\begin{array}{l}\text { Is bilateral lower limb lengthening appropriate } \\
\text { for achondroplasia? midterm analysis of the } \\
\text { complications and quality of life }\end{array}$ & $\begin{array}{l}\text { Retrospective case } \\
\text { control }\end{array}$ & $\begin{array}{l}22 \text { patients } \\
\text { Aged } 8-25\end{array}$ & Level 4 \\
\hline 9 & $\begin{array}{l}\text { McKee et al. } \\
1998^{40}\end{array}$ & $\begin{array}{l}\text { Health status after Ilizarov reconstruction of } \\
\text { post-traumatic lower-limb deformity }\end{array}$ & $\begin{array}{l}\text { Prospective case } \\
\text { series }\end{array}$ & $\begin{array}{l}22 \text { patients } \\
\text { Aged } 18-72 \\
12 \text { men, } 10 \text { women }\end{array}$ & Level 4 \\
\hline 10 & $\begin{array}{l}\text { Mekhail et al. } \\
2004^{41}\end{array}$ & $\begin{array}{l}\text { Bone transport in the management of posttrau- } \\
\text { matic bone defects in the lower extremity }\end{array}$ & Retrospective study & $\begin{array}{l}19 \text { patients } \\
\text { Mean age } 36.4\end{array}$ & Level 4 \\
\hline 11 & Modin et al. $2009^{6}$ & $\begin{array}{l}\text { Postoperative impact of daily life after primary } \\
\text { treatment of proximal/distal tibiafracture with } \\
\text { llizarov external fixation }\end{array}$ & $\begin{array}{l}\text { Prospective descrip- } \\
\text { tive research design }\end{array}$ & $\begin{array}{l}14 \text { men, } 5 \text { women } \\
20 \text { patients } \\
\text { Aged } 34-76\end{array}$ & Level 4 \\
\hline 12 & $\begin{array}{l}\text { Ramos et al. } \\
2013^{42}\end{array}$ & $\begin{array}{l}\text { The llizarov external fixator-a useful alternative } \\
\text { for the treatment of proximal tibial fractures a } \\
\text { prospective observational study of } 30 \text { consecu- } \\
\text { tive patients }\end{array}$ & $\begin{array}{l}\text { Prospective observa- } \\
\text { tional study }\end{array}$ & $\begin{array}{l}30 \text { patients } \\
\text { Aged } 18-74 \text { (mean } 51) \\
18 \text { men, } 12 \text { women }\end{array}$ & Level 4 \\
\hline 13 & $\begin{array}{l}\text { Rozbruch et al. } \\
2008^{43}\end{array}$ & $\begin{array}{l}\text { Repair of tibial nonunions and bone defects with } \\
\text { the taylor spatial frame }\end{array}$ & $\begin{array}{l}\text { Prospective case } \\
\text { series }\end{array}$ & $\begin{array}{l}38 \text { patients } \\
\text { Aged } 8-72 \text { (mean } 43 \text { ) } \\
30 \text { men, } 8 \text { women }\end{array}$ & Level 4 \\
\hline 14 & $\begin{array}{l}\text { Spiegl et al. } \\
2013^{44}\end{array}$ & $\begin{array}{l}\text { Clinical course, complication rate and outcome } \\
\text { of segmental resection and distraction } \\
\text { osteogenesis after chronic tibial osteitis }\end{array}$ & $\begin{array}{l}\text { Prospective case } \\
\text { series }\end{array}$ & $\begin{array}{l}25 \text { patients } \\
\text { Aged } 20-60 \text { (mean 46) } \\
22 \text { men, } 3 \text { women }\end{array}$ & Level 4 \\
\hline 15 & Tellisi et al. $2009^{45}$ & $\begin{array}{l}\text { Joint preservation of the osteoarthritic ankle } \\
\text { using distraction arthroplasty }\end{array}$ & $\begin{array}{l}\text { Prospective case } \\
\text { series }\end{array}$ & $\begin{array}{l}25 \text { patients } \\
\text { Aged } 16-73 \text { (mean } 43 \text { ) } \\
16 \text { females, } 7 \text { males }\end{array}$ & Level 4 \\
\hline
\end{tabular}

significant improvement at the 2-year follow-up. However, the final mental component summary (MCS) scores were comparable to a normal population suggesting that, following treatment, the patients' mental wellbeing returned to comparable levels similar to that of the normal population in most cases.

In study 14, the median scores of both physical component summary (PCS) and MCS were above those for the normal age- matched population. This may be explained by several patients having formed a more positive outlook on life in general after having survived a serious injury with the lower limb; this indicates that this PROM is sensitive to these changes.

These results support the SF-36 as a responsive and a reliable tool. Although the SF-36 was not inclusive of all items appropriate for measuring changes in HRQoL, in most of these patient groups, it 


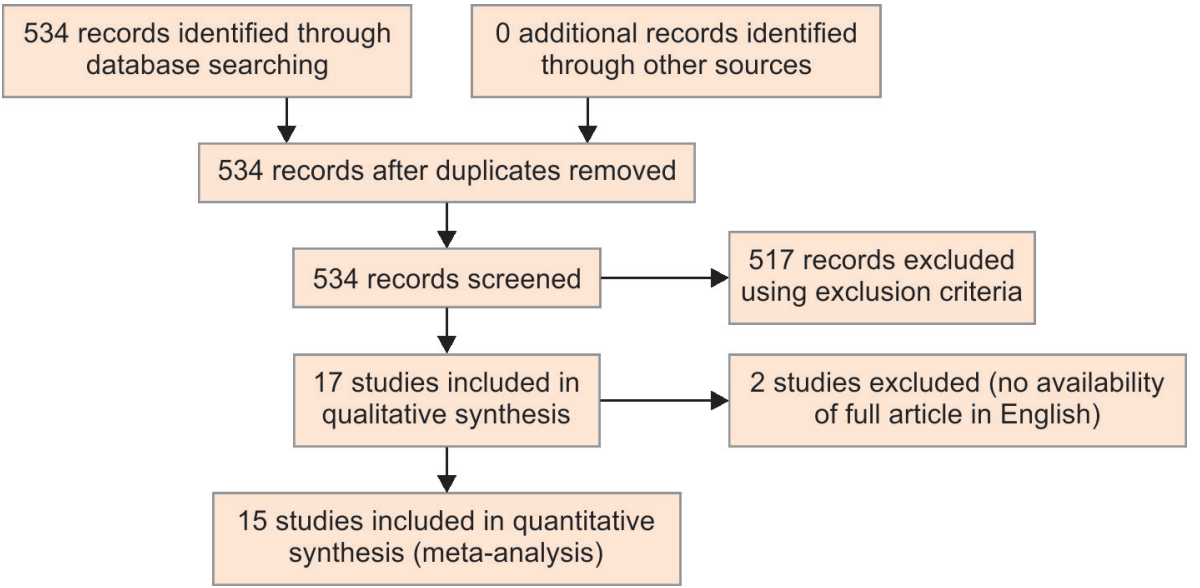

Fig. 1: PRISMA flow diagram displaying the search criteria used to determine which studies to include

could provide the best source of items and general domains which are valid, reproducible, and responsive.

SF-12 is a shortened version of the SF-36. It contains 12 of the items from SF-36. This is generally seen as not capturing as much information as the SF-36 and, as such, has less content validity.

However, in all three studies, it was used in ref. 2, 3 and 7, it showed responsiveness between pre- and postoperative physical and mental component scores and, therefore, could be used where a shortened form is more acceptable.

\section{Nottingham Health Profile (NHP)}

The NHP, ${ }^{15}$ which can be completed in 5 minutes, consists of two parts. The first part focuses on health and comprises of 38 items which deal with pain, energy, sleep, mobility, emotional reaction, and social isolation. ${ }^{16}$ The second part focuses on life areas affected (Nottingham Health Profile) and consists of seven items which deal with problems regarding occupation, housework, social life, family life, sexual function, hobbies, and holidays. ${ }^{16}$ The second part of the NHP is optional and can be omitted without affecting the test results. ${ }^{17}$

All questions have only yes or no answer options and each section score is weighted. The higher the score, the greater the number and severity of problems. The highest score in any section is $100 .^{18}$

The NHP has been used for a study comparing limb salvage and amputation outcomes. This may be useful as it addresses some of the psychological issues around this group of patients. ${ }^{19}$ However, the score uses a weighting of outcomes to produce the overall score which indicates that the items on their own may not have the same properties. Only two studies used the NHP., 12 Study 9 demonstrated that the SF-36 showed significant responsiveness where the NHP did not. As they both purport to measure the same thing, it can be suggested that the NHP lacks criterion validity in comparison to the SF-36.

\section{Euro Quality}

This PROM was used in one study (study 12). The EQ-5D values and NHP total scores show that the overall function was severely affected at 4 weeks (Schatzker I-IV: 0.66, Schatzker V-VI: 0.59), but improved at 1 year (Schatzker I-IV: 0.89, Schatzker V-VI: 0.80). This improvement mimics that seen in the EQ-5D questionnaire suggesting that both questionnaires are valid and responsive.

\section{Children's Health RAND}

In study 4, a functional score was determined with the use of the physical function subscale of the Children Health Information Service Rand Scale developed by Eisen et al. ${ }^{20}$ This questionnaire, which has been shown previously to be reliable and valid, consists of 13 questions with each yes answer given a score of 1 point and each no answer given a score of 0 points so that 0 points is the best score and 13 points the worst possible score. The 13 questions are divided into four categories: mobility, physical activity, role activity, and self-care activities.

The physical function subscale score for the entire study population was 0.7 points (range $0-5$ points) with 42 children $(93 \%)$ having no limitations in daily activities and 3 children (7\%) having some limitation in activities. Although specific for children, this PROM highlights the physical aspects only and does not take into consideration other aspects that also contribute to QoL (mental wellbeing, social functioning, etc.) which the SF-36 includes.

\section{Musculoskeletal Function}

\section{American Academy of Orthopedic Surgeons (AAOS) Lower Limb Score}

This PROM has been validated across sports, foot, ankle, knee, hip, and trauma pathologies. ${ }^{21-25}$ Its use for measuring outcomes from treatment with circular frames is quite limited. This may change as it is a functional outcome tool for the American Academy of Orthopedic Surgeons.

The AAOS lower limb score was used in three studies. ${ }^{2,8,13}$ Studies 2 and 8 were prospective studies which showed a statistically significant increase from preoperative to postoperative scores suggesting a responsiveness to changes in the study group. These studies were similar for the patient groups (tibial non-unions) and, therefore, it cannot be assumed that this score will be as good for other conditions. Study 8 compared postoperative scores to a control population and noted no significant changes in the AAOS score. However, changes were noted in the SF-36 physical component summary, which were almost significant ( $p=0.051)$, suggesting that the SF-36 may be more appropriate at measuring outcomes in this patient group.

\section{Musculoskeletal Function Assessment (MFA)}

The MFA has been developed specifically for use with patients with musculoskeletal disorders of the extremities. ${ }^{26,27}$ It has not been 
Table 2: Summarizing study time points, PROMs used, and summary of findings for each paper

\begin{tabular}{ll}
\hline No & Key methodology \\
\hline $1 \quad$ & Outcomes taken \\
& - Preoperatively \\
& - 6 months, 1 year, 2 years, 2.5 years after fram \\
& removal \\
& Outcome used \\
& Lower limb TESS, climbing stairs, walking rate \\
& ability to stand from sitting position \\
& \\
& Outcomes taken \\
& - Upon admission \\
& 18-61 months after discharge from care \\
& Outcome used \\
& AAOS lower limb, BPI, SF-12, Time trade-off
\end{tabular}

3 Outcomes taken

- Postoperatively at median of 55 months [mean 62, (26-99)] after date of injury

Outcomes used

- Lysholm knee questionnaire

- Tegner activity scale

- Olerud and molander ankle score

- Short-Form (SF)-12.

4 Outcomes taken

- Postoperatively

Outcomes used

- Children's health information rand acale

5 Outcomes taken

- Pre-operatively

- Pre frame removal (SF-36 only)

- 6 weeks after frame removal

Outcome used

Turkish SF-36, KS knee score, KS functional score, HSS knee score

Summary of results

Differences between scores were expressed as a ratio. Statistically significant differences were seen in:

TESS Pre-op to 6 months (1.15), 6 months to 1 year (1.18), 1-2 years (1.08)

Walking speed Pre-op to 6 months (1.18), 6 months to 1 year (1.08), 1-2 years (1.01)

Sit to stand 6 months to 1 year (1.10), 1-2 years (1.02)

Stair climbing 6 months to 1 year (1.08), 1-2 years (1.02)

No statistically significant differences between femoral or tibial non-union

Statistically significant increases in scores from admission to discharge were seen for

AAOS lower limb (39-78)

SF-12 Physical component summary (26.5-35.3) and mental component summary (41.6-48.7)

BPI Statistically significant decreases in scores from admission to discharge for intensity (10/10-0.9/10) and interference scores (5.5/10-2.2/10)

Time trade-off suggested patients gained 5.3 QALYs

- Tegner activity scale $2.8(p=0.55)$

- Lysholm $88(p=0.81)$

- Olerud and Molander ankle score $75(p=0.69)$

- SF-12 physical component $51(p=0.68)$

- SF-12 mental component $53(p=0.73)$

- SF-12: when compared with age-matched figures, the median scores (physical component 55, mental component 57) are above the normal age-matched population

- Physical function subscale functional score for the entire study population was 0.7 point (range, $0-5$ points)

- 42 children (93\%) having no limitations in daily activities

- 3 children (7\%) had some limitation in activities

SF-36 Statistically significant sequential increases in preoperative, pre frame removal and 6 weeks post frame removal scores were seen in bodily pain (18.9-62.1-81.7), general health (22.6-53.8-82.1), vitality (40.2-67.9-84.5), social function (34.3-52.8-92.1) and mental health (42.1-65.9-82.5) components

Statistically significant increases between preoperative and 6 weeks post frame removal were seen in physical function (38.1-85.7), physical role (31.0-94.0) and emotional role (39.4-88.7). Physical role also showed a statistically significant decrease between preop and pre frame removal scores (31.0-16.7)

The post frame removal scores for physical function, pain, general heath, vitality and mental health components of the SF-36 showed statistically significant correlation with duration of symptoms

Statistically significant increases in preoperative and 6 weeks post frame removal were seen in KS Knee Score (51-89), KS functional score (43-85), HSS knee score (60-90). Non-significant correlation between patients with and without infection

- Preoperatively 40 (12-67) improved to 71 (34-97) postoperatively

- Improvement by 31 statistically significant $(p<0.001)$

- Preoperatively

- Postoperatively

Outcomes used

- AOFAS

7 Outcomestaken

- Preoperatively

- 19 months postoperatively (range 15-35)

Outcome used

OKSSF-12, Visual analogue pain scores
Statistically significant improvement in preoperative to postoperative scores seen in: OKS from 28.7-35.4

SF-12 MSC from 42.2-53.5

SF-12 PCS from 42.8-44.6

VAS (pain)

Contd... 


\begin{tabular}{|c|c|c|}
\hline No & Key methodology & Summary of results \\
\hline \multirow[t]{3}{*}{8} & \multirow{3}{*}{$\begin{array}{l}\text { Outcomes taken } \\
\text { - } 5 \text { years follow up } \\
\text { Outcome used } \\
\text { AAOS lower limb, SF-36, RSEM }\end{array}$} & AAOS lower limb No significant differences seen \\
\hline & & $\begin{array}{l}\text { SF-36 Higher scores in the physical component summary for the non surgical } \\
\text { group compared to the surgical group ( } 55.63 \text { vs } 45.04) \text { although this difference } \\
\text { was not quite significant }(p=0.051)\end{array}$ \\
\hline & & $\begin{array}{l}\text { RSEM Statistically significantly higher scores for surgical group compared to the } \\
\text { non-surgical group (22.1 vs 19) }\end{array}$ \\
\hline \multirow[t]{7}{*}{9} & \multirow{7}{*}{$\begin{array}{l}\text { Outcomes taken } \\
\text { - Preoperatively } \\
\text { - In frame } \\
\text { - } 3,6,12 \text { and } 24 \text { r } \\
\text { Outcome used } \\
\text { SF-36, NHP }\end{array}$} & $\begin{array}{l}\text { Statistically significant decrease in scores during time in frame compared to pre- } \\
\text { operative scores in SF- } 36 \text { role-physical only. There was no statistically significant } \\
\text { change in the roughly corresponding NHP physical mobility }\end{array}$ \\
\hline & & $\begin{array}{l}\text { Statistically significant increase in } 24 \text { month postoperative scores compared to } \\
\text { preoperative scores for: }\end{array}$ \\
\hline & & SF-36 General health (35-57), bodily pain (37-62), mental health \\
\hline & & (36-69), role emotional (39-75), social function (33-67), overall (36-58). \\
\hline & & NHP Physical mobility (34-65), sleep (31-69), average (39-67) \\
\hline & & $\begin{array}{l}\text { NHP pain and social isolation components showed non-significant improvements } \\
(33-61) \text { and (48-70) }\end{array}$ \\
\hline & & $\begin{array}{l}\text { All components of SF- } 36 \text { and NHP which gave statistically significant } \\
\text { improvements at } 24 \text { months postoperatively showed non-significant sequential } \\
\text { increases between preoperative, in frame, } 12 \text { month and } 24 \text { month post-op scores }\end{array}$ \\
\hline \multirow[t]{6}{*}{10} & \multirow{3}{*}{$\begin{array}{l}\text { Outcomes taken } \\
\text { - Postoperatively } \\
\text { - } 68.7 \text { months (range, } 24-146 \text { months }\end{array}$} & Statistically significant lower scores for patients compared to control population seen in: \\
\hline & & SF-36 Physical functioning 63.33 (84.15) \\
\hline & & SF-36 Bodily pain 58.00 (80.96) \\
\hline & \multirow{3}{*}{$\begin{array}{l}\text { Outcome used } \\
\text { SF-36AAOS lower limb }\end{array}$} & SF-36 Role emotional 58.33 (81.26) \\
\hline & & $\begin{array}{l}\text { Lower scores were also noted for all other elements of the SF- } 36 \text { but with no } \\
\text { significance }\end{array}$ \\
\hline & & $\begin{array}{l}\text { Study noted that individual scores varied depending on perceived clinical } \\
\text { recovery of patient }\end{array}$ \\
\hline \multirow[t]{6}{*}{11} & \multirow{6}{*}{$\begin{array}{l}\text { Outcomes taken } \\
\text { - } 2 \text { weeks postoperatively } \\
\text { - } 4 \text { weeks postoperatively } \\
\text { Outcome used } \\
\text { Semi structured questionnaire addressing } \\
\text { household chores, } \\
\text { hygiene, activities outside the home, recreational } \\
\text { activities and social activities }\end{array}$} & Limitations divided into: \\
\hline & & $\begin{array}{l}\text { Household chores Difficulties with cooking, washing up and carrying objects re- } \\
\text { ported. Additionally problems associated with travelling around the home and up } \\
\text { and down stairs. Fatigue, pain and swelling also limited activities in these areas }\end{array}$ \\
\hline & & $\begin{array}{l}\text { Hygiene Some people experienced limitations with washing themselves and sitting } \\
\text { on the toilet. Travel around the home was an additional factor making this difficult }\end{array}$ \\
\hline & & $\begin{array}{l}\text { Limitations outside the home Mobility outside the home was reduced, especially by } \\
\text { not being able to drive, walk long distances, travel on uneven surfaces, climb stairs } \\
\text { or travel unsupported }\end{array}$ \\
\hline & & $\begin{array}{l}\text { Limitations to social relations Most people had friends visit them in their own home, } \\
\text { and people expressed that outside environments and activities were easily accessible }\end{array}$ \\
\hline & & $\begin{array}{l}\text { Experience of having an Ilizarov fixation: There was a mix of feelings surrounding } \\
\text { the fixator, with many people expressing embarrassment about being seen with } \\
\text { the apparatus in public }\end{array}$ \\
\hline \multirow[t]{6}{*}{12} & \multirow{6}{*}{$\begin{array}{l}\text { Outcomes taken } \\
\text { - Postoperatively at 4, } 12 \\
\text { - NB KOOS at 1-5 years fo } \\
\text { Outcomes used } \\
\text { - VAS } \\
\text { - European Qol (EQ-5D) } \\
\text { - NHP } \\
\text { - KOOS }\end{array}$} & $\begin{array}{l}\text { - Differences between the Pain (VAS), EQ-5D, NHP values at one year and the } \\
\text { KOOS questionnaire were not significant }\end{array}$ \\
\hline & & - The EQ-5D values and NHP total scores show that the overall function was \\
\hline & & \\
\hline & & $\begin{array}{l}\text { EQ-5D } \\
\text {. Groun I (Schatzker I-IV) } 4 \text { weeks }(066) \rightarrow 1 \text { vear (0 89) }\end{array}$ \\
\hline & & - Group II (Schatzker V-VI): 4 weeks $(0.59) \rightarrow 1$ year $(0.80)$ \\
\hline & & \\
\hline \multirow[t]{4}{*}{13} & \multirow{3}{*}{$\begin{array}{l}\text { Outcomes taken } \\
\text { - Preoperatively } \\
\text { - } 37 \text { months (15-63) post frame removal }\end{array}$} & Statistically significant improvement in preoperative to postoperative scores seen in: \\
\hline & & SF-36 physical function (19-51) \\
\hline & & SF-36 physical role $(21-51)$ \\
\hline & $\begin{array}{l}\text { Outcome used } \\
\text { SF-36, AAOS lower limb }\end{array}$ & AAOS lower limb (56-82) \\
\hline
\end{tabular}

Contd... 
Contd...

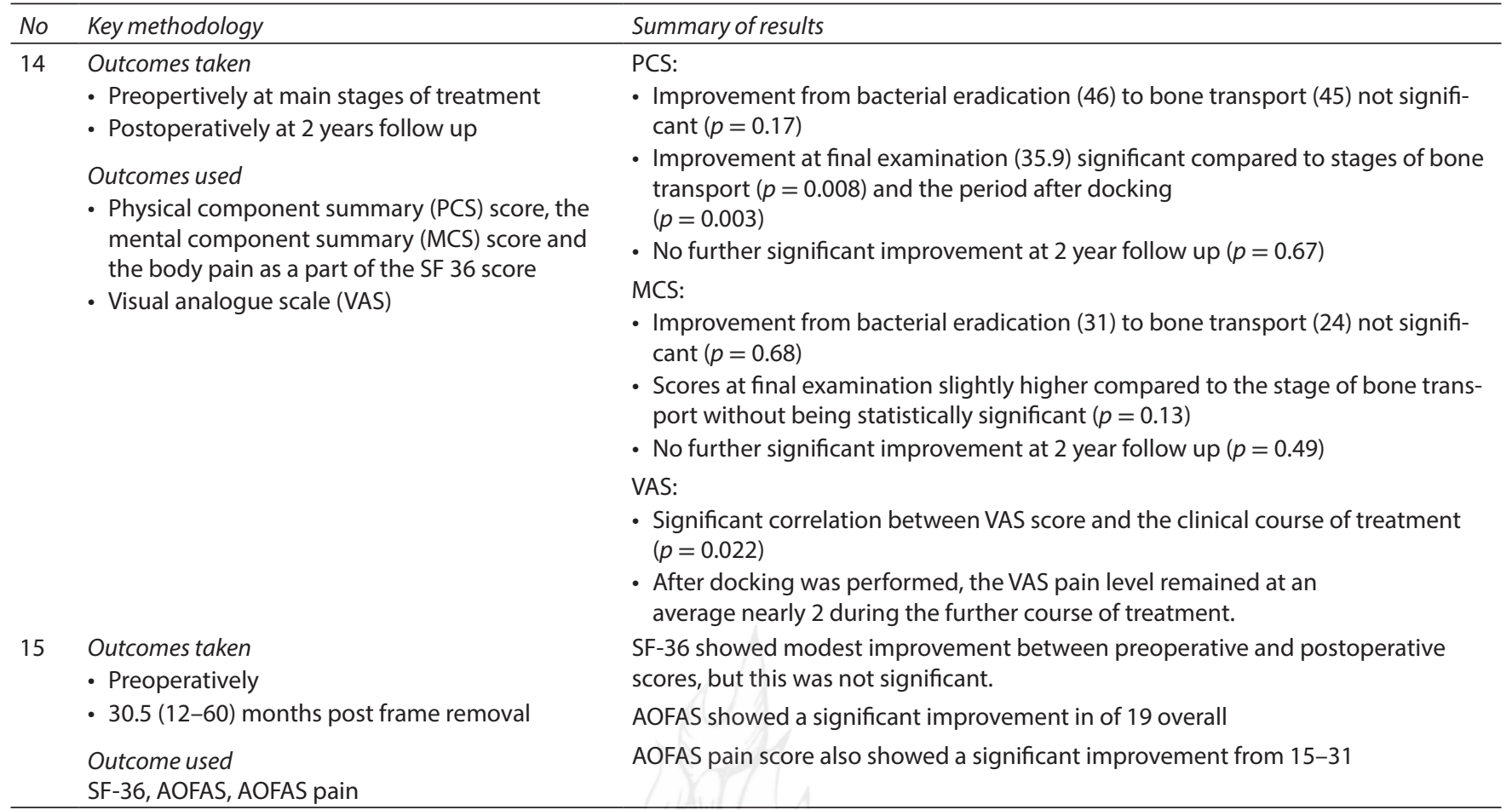

used in the existing studies but has shown limited validity for tibial shaft fractures. ${ }^{28}$ It can differentiate between patient treatment and fracture severity in tibial plafond fractures, ${ }^{29}$ therefore, indicating construct validity, and has been recommended as a useful tool in analyzing outcomes of outer extremity injury. ${ }^{14,30}$ The items used were developed from a bank for the musculoskeletal outcomes study (MOS); this may be a useful source for other items.

\section{Toronto Extremity Salvage Score (TESS) Lower Limb}

This was developed to analyze outcomes of limb salvage after osteosarcomas. There has been very limited use outside this area. A more appropriate PROM would be the lower extremity measure which was developed from Toronto Extremity Salvage Score (TESS) but designed for use in limb trauma patients. This has been evaluated fully in hip fractures for which it was deemed the most appropriate PROM. ${ }^{31}$

The TESS lower limb was used in study 1. It showed responsiveness to changes in patient recovery over time. This reflects increases in clinical outcomes suggesting a degree of construct validity. Its reliability is limited as it was not used in any other external fixator study; as a specifically designed tool for limb salvage, it may not be appropriate for use in all frame patients.

\section{Tegner Activity Score}

The Tegner Activity score used in study 3 complements other scores such as the Lysholm knee score for patients with ligamentous injuries because it reflects the ability for activity rather than the absence of negative events such as pain, locking, and giving way. ${ }^{32}$ Activity levels are scored between 0 and 10, where 0 is "on sick leave or disability" and 10 is "participation in competitive sports such as football at a national or international elite level." It is the most widely used activity scoring system for patients with knee disorders. However, it does not take into account that individuals may be able to participate at a higher level of activity but consciously choose not to or that some people will participate at a higher level of activity but with limitations.
A preoperative comparison cannot be made as postoperative scores are available (2.8) only. This score describes a level of activity such as "being in work or light labor" and "walking on uneven ground possible, but impossible to back-pack or hike." In comparison, the Lysholm score (88) reflects a level of "fair to good" which ranks in the middle centile of possible outcomes as opposed to the Tegner score which is on the second level out of 10 levels. This may suggest that the responsiveness of this score is quite low. ${ }^{33}$

\section{Joint-Specific Measures}

Several studies used joint-specific measures., ${ }^{3,5-7,12,15}$ Study 5 suggested that the SF-36 might be more useful in measuring patient health than the Knee Society (KS) knee score, KS functional score, and HSS knee score as this had shown evidence of statistically significant responsiveness whereas the others did not. Study 15 , however, showed that AOFAS was a statistically significantly responsive tool and that the SF-36 was not. The AOFAS was also statistically significant in study 6 with a postoperative improvement of 31 points as compared to the preoperative score. Study 7 does not suggest one or other score is more useful but does indicate that both are (approximately) equally sensitive to change.

The lack of any one prevailing study as being responsive suggests that neither is more appropriate and both contain analysis of issues not important to some patient groups.

The knee injury and osteoarthritis outcome score (KOOS) used in study 12 encompasses symptoms, stiffness, pain, activities of daily living, sports and recreational activities, and QoL. Differences between the pain (Visual Analogue Scale, VAS), EQ-5D, NHP values at 1 year and the KOOS questionnaire were not significant, suggesting that it is responsive.

\section{Pain}

Two main pain measures were used: a VAS and a Brief Pain Inventory (BPI). The SF-36 has a pain component but this did not show a 
statistically significant responsiveness in two studies ${ }^{13,15}$ of the five. ${ }^{5,8,9,13,15}$ Lack of validity in study 8 may reflect lack of difference in this domain. Both BPI and VAS showed statistical responsiveness to the stage of treatment; in study 14 , there was a correlation between the VAS score and the clinical course of treatment, reflecting good responsiveness and sensitivity.

Due to the nature of Ilizarov treatment, the BPI may be a more appropriate way to test pain at different points in time. One study ${ }^{11}$ used qualitative data to assess the impact of Ilizarov treatment on daily life. The key findings are summarized in Table 2. Although these may not be universal to all patients and consisted of only a small patient sample at one point in time, the issues raised may form a valuable basis for PROM items.

\section{Discussion}

The literature review has revealed that no PROM has been analyzed against all the COSMIN criteria. In addition, inferences and conclusions drawn from the literature review are limited. Some studies showed trends suggesting responsiveness of validity but without a statistical significance. As sample sizes were small, the ability to determine whether this indicates a lack of overall validity of the PROM for this patient group is hampered. In addition to this limitation, the lack of any one or combination of studies to encompass the broad range of indications for patient treatment with a frame meant that the results were limited in their reliability (i.e., how representative these are for all frame patients).

The use of individual PROMs and other PROMs used to assess HRQoL and musculoskeletal function of the lower limb were also analyzed. It is known that patients treated in a frame do experience different health outcomes to other orthopedic patients; for this reason, inferences drawn about the validity of the PROMs in the studies referenced may be limited in their representation of frame patients. None of the PROMs identified or PROM domains identified were assumed to be complete in representing all patient outcomes or as being useful tools for all patient groups.

Circular frame patients provide a complex group of subjects which can encompass a multitude of different pathologies. The period of application of a frame may vary considerably which makes the design of a single PROM challenging. It was shown in the studies reviewed that a collection of different PROM scores may be required along with a specific scoring system. Some scoring systems have been developed, such as the Harris Hip Score, which relies on a combination of clinical measures and patient opinions to generate a score; using such a combined approach could be explored as regular clinical follow-up is required usually for these complex patients.

As a summary of the findings of this systematic review, we identified that the SF-36 should be used as the main source of HRQoL items. The AAOS lower limb, MFA, TESS lower limb PROMs, and MOS items should be considered as sources of functionspecific items and some HRQoL items. The intensity section of $\mathrm{BPI}$ should be the main measurement of pain and interference scores will only be used if this is raised as a potential outcome from a content analysis of patient interviews. Apart from pain, no PROM showed the appropriateness, validity, or reliability required to justify using whole sections as measurements in the development of another PROM. However, developing items from these PROMs has the advantage that items developed may have the good acceptability properties normally associated with fully evaluated PROMs.

\section{Conclusion}

PROMs are being recognised increasingly as an important tool for evaluation of health by clinicians, auditors, and patients. The indications for use in frame patients are strong and this has been expressed by the expert health professionals in this study. Our findings indicate that none of the PROMs analyzed in this systematic review are truly representative of the health outcomes specific to this patient group. Based on this work we have developed a PROM score in our institution (The Stanmore Limb Reconstruction Score, SLRS). The score can be seen in the Appendix below. We are currently working on a prospective evaluation of its usefulness in this population group.

\section{Compliance with Ethical Standards}

This article is a review article and does not contain any new human participants or animal work.

\section{Appendix: Stanmore Limb Reconstruction SCORE (SLRS)}

\section{Pain}

Please answer the following questions regarding pain you feel in the leg which has/is being treated with the llizarov external fixator. If you have received treatment with an llizarov external fixator on both legs, please describe the pain in the leg which is the most painful.

(1) For the last week, please rate your pain at its worst

\begin{tabular}{lllllllllll}
\hline 0 & 1 & 2 & 3 & 4 & 5 & 6 & 7 & 8 & 9 & 10 \\
\hline No & & & & & & & & & & $\begin{array}{l}\text { Unbearable } \\
\text { pain }\end{array}$ \\
pain & & & & & & & & & & \\
\hline
\end{tabular}

(2) For the past week please rate your pain at its least

\begin{tabular}{lllllllllll}
\hline 0 & 1 & 2 & 3 & 4 & 5 & 6 & 7 & 8 & 9 & 10 \\
\hline No & & & & & & & & & & $\begin{array}{l}\text { Unbearable } \\
\text { pain }\end{array}$ \\
pain & & & & & & & & & & \\
\hline
\end{tabular}

(3) How much pain are you in now?

\begin{tabular}{lllllllllll}
\hline 0 & 1 & 2 & 3 & 4 & 5 & 6 & 7 & 8 & 9 & 10 \\
\hline $\begin{array}{l}\text { No } \\
\text { pain }\end{array}$ & & & & & & & & & & $\begin{array}{l}\text { Unbearable } \\
\text { pain }\end{array}$ \\
\hline
\end{tabular}

(4) For the past week, please describe the amount of waking time in which you are in pain

\begin{tabular}{lllll}
\hline 1 & 2 & 3 & 4 & 5 \\
\hline $\begin{array}{l}\text { None of the } \\
\text { time }\end{array}$ & $\begin{array}{l}\text { A little of } \\
\text { the time }\end{array}$ & $\begin{array}{l}\text { Some of } \\
\text { the time }\end{array}$ & $\begin{array}{l}\text { Most of the } \\
\text { time }\end{array}$ & $\begin{array}{l}\text { All of the } \\
\text { time }\end{array}$ \\
\hline
\end{tabular}

\section{Sleep}

Please describe your sleep for the past week

(1) During the past week, how difficult was it to get a deep and comfortable sleep?

\begin{tabular}{lllll}
\hline 1 & 2 & 3 & 4 & 5 \\
\hline Never & It is a little & Difficult some & Difficult most of & Always \\
difficult & bit difficult & of the time & the time & difficult \\
\hline
\end{tabular}

(2) How often do you get enough sleep to feel rested in the morning?

\begin{tabular}{lllll}
\hline 1 & 2 & 3 & 4 & 5 \\
\hline $\begin{array}{l}\text { Always feel } \\
\text { rested }\end{array}$ & $\begin{array}{l}\text { Most of the } \\
\text { time I feel } \\
\text { rested }\end{array}$ & $\begin{array}{l}\text { Some of the } \\
\text { time }\end{array}$ & $\begin{array}{l}\text { Rarely do I } \\
\text { feel rested }\end{array}$ & $\begin{array}{l}\text { Never rested/ } \\
\text { always feel } \\
\text { tired }\end{array}$ \\
\hline
\end{tabular}


A Systematic Review of PROMs Used in Circular Frame Fixation

\section{Social/relationships}

This section looks at your social life and relationships. Please answer the questions in regard to the leg which is/has been treated with the llizarov external fixator.

(1) During the past week, to what extent has your leg interfered with normal social activities with friends, family and social groups

\begin{tabular}{lllll}
\hline 1 & 2 & 3 & 4 & 5 \\
\hline Not at all & $\begin{array}{l}\text { A little of } \\
\text { the time }\end{array}$ & $\begin{array}{l}\text { Some of the } \\
\text { time }\end{array}$ & $\begin{array}{l}\text { Most of the } \\
\text { time }\end{array}$ & $\begin{array}{l}\text { All of the } \\
\text { time }\end{array}$ \\
\hline
\end{tabular}

(2) During the past week, do you feel the current situation with your leg has affected your ability to be intimate with those close to you?

\begin{tabular}{lllll}
\hline 1 & 2 & 3 & 4 & 5 \\
\hline Not at all & $\begin{array}{l}\text { A little of } \\
\text { the time }\end{array}$ & $\begin{array}{l}\text { Some of the } \\
\text { time }\end{array}$ & $\begin{array}{l}\text { Most of the } \\
\text { time }\end{array}$ & $\begin{array}{l}\text { All of the } \\
\text { time }\end{array}$ \\
\hline
\end{tabular}

\section{Physical Function}

\section{Mobility}

Please answer the following questions in regards to the previous 4 weeks

(1) How difficult is it for you to get in and out of a car

\begin{tabular}{lllll}
\hline 1 & 2 & 3 & 4 & 5 \\
\hline Not at all & $\begin{array}{l}\text { A little of } \\
\text { the time }\end{array}$ & $\begin{array}{l}\text { Some of the } \\
\text { time }\end{array}$ & $\begin{array}{l}\text { Most of the } \\
\text { time }\end{array}$ & $\begin{array}{l}\text { All of the } \\
\text { time }\end{array}$ \\
\hline
\end{tabular}

(2) How difficult is it for you to use public transport

\begin{tabular}{lllll}
\hline 1 & 2 & 3 & 4 & 5 \\
\hline Not at all & $\begin{array}{l}\text { A little of } \\
\text { the time }\end{array}$ & $\begin{array}{l}\text { Some of the } \\
\text { time }\end{array}$ & $\begin{array}{l}\text { Most of the } \\
\text { time }\end{array}$ & $\begin{array}{l}\text { All of the } \\
\text { time }\end{array}$ \\
\hline
\end{tabular}

(3) How difficult is it for you to move around the whole of the house unassisted

\begin{tabular}{lllll}
\hline 1 & 2 & 3 & 4 & 5 \\
\hline Not at all & $\begin{array}{l}\text { A little of } \\
\text { the time }\end{array}$ & $\begin{array}{l}\text { Some of the } \\
\text { time }\end{array}$ & $\begin{array}{l}\text { Most of the } \\
\text { time }\end{array}$ & $\begin{array}{l}\text { All of the } \\
\text { time }\end{array}$ \\
\hline
\end{tabular}

(4) How difficult is it for you to leave home unassisted

\begin{tabular}{lllll}
\hline 1 & 2 & 3 & 4 & 5 \\
\hline Not at all & $\begin{array}{l}\text { A little of } \\
\text { the time }\end{array}$ & $\begin{array}{l}\text { Some of the } \\
\text { time }\end{array}$ & $\begin{array}{l}\text { Most of the } \\
\text { time }\end{array}$ & $\begin{array}{l}\text { All of the } \\
\text { time }\end{array}$ \\
\hline
\end{tabular}

\section{Activities Around the Home}

During the last week, has your leg interfered with your ability to

(1) Do household chores such as vacuuming

\begin{tabular}{lllll}
\hline 1 & 2 & 3 & 4 & 5 \\
\hline Not at all & $\begin{array}{l}\text { A little of } \\
\text { the time }\end{array}$ & $\begin{array}{l}\text { Some of the } \\
\text { time }\end{array}$ & $\begin{array}{l}\text { Most of the } \\
\text { time }\end{array}$ & $\begin{array}{l}\text { All of the } \\
\text { time }\end{array}$ \\
\hline
\end{tabular}

(2) Stand for a long period time

\begin{tabular}{lllll}
\hline 1 & 2 & 3 & 4 & 5 \\
\hline Not at all & $\begin{array}{l}\text { A little of } \\
\text { the time }\end{array}$ & $\begin{array}{l}\text { Some of the } \\
\text { time }\end{array}$ & $\begin{array}{l}\text { Most of the } \\
\text { time }\end{array}$ & $\begin{array}{l}\text { All of the } \\
\text { time }\end{array}$ \\
\hline
\end{tabular}

(3) Carry things around the home

\begin{tabular}{lllll}
\hline 1 & 2 & 3 & 4 & 5 \\
\hline Not at all & $\begin{array}{l}\text { A little of } \\
\text { the time }\end{array}$ & $\begin{array}{l}\text { Some of the } \\
\text { time }\end{array}$ & $\begin{array}{l}\text { Most of the } \\
\text { time }\end{array}$ & $\begin{array}{l}\text { All of the } \\
\text { time }\end{array}$ \\
\hline
\end{tabular}

(4) Bend to pick things up

\begin{tabular}{lllll}
\hline 1 & 2 & 3 & 4 & 5 \\
\hline Not at all & $\begin{array}{l}\text { A little of } \\
\text { the time }\end{array}$ & $\begin{array}{l}\text { Some of the } \\
\text { time }\end{array}$ & $\begin{array}{l}\text { Most of the } \\
\text { time }\end{array}$ & $\begin{array}{l}\text { All of the } \\
\text { time }\end{array}$ \\
\hline
\end{tabular}

(5) Go shopping

\begin{tabular}{lllll}
\hline 1 & 2 & 3 & 4 & 5 \\
\hline Not at all & $\begin{array}{l}\text { A little of } \\
\text { the time }\end{array}$ & $\begin{array}{l}\text { Some of the } \\
\text { time }\end{array}$ & $\begin{array}{l}\text { Most of the } \\
\text { time }\end{array}$ & $\begin{array}{l}\text { All of the } \\
\text { time }\end{array}$ \\
\hline $\begin{array}{llll}\text { (6) Climb stairs } \\
1\end{array}$ & & & \\
\hline Not at all & $\begin{array}{l}\text { A little of } \\
\text { the time }\end{array}$ & $\begin{array}{l}\text { Some of the } \\
\text { time }\end{array}$ & $\begin{array}{l}\text { Most of the } \\
\text { time }\end{array}$ & $\begin{array}{l}\text { All of the } \\
\text { time }\end{array}$ \\
\hline
\end{tabular}

Activities Outside

During the last week, has your leg interfered with your ability to

(1) Walk outdoors/ leave your house/place of residence

\begin{tabular}{lllll}
\hline 1 & 2 & 3 & 4 & 5 \\
\hline Not at all & $\begin{array}{l}\text { A little of } \\
\text { the time }\end{array}$ & $\begin{array}{l}\text { Some of the } \\
\text { time }\end{array}$ & $\begin{array}{l}\text { Most of the } \\
\text { time }\end{array}$ & $\begin{array}{l}\text { All of the } \\
\text { time }\end{array}$ \\
\hline
\end{tabular}

(2) Walk $100 \mathrm{~m}$

\begin{tabular}{lllll}
\hline 1 & 2 & 3 & 4 & 5 \\
\hline Not at all & $\begin{array}{l}\text { A little of } \\
\text { the time }\end{array}$ & $\begin{array}{l}\text { Some of the } \\
\text { time }\end{array}$ & $\begin{array}{l}\text { Most of the } \\
\text { time }\end{array}$ & $\begin{array}{l}\text { All of the } \\
\text { time }\end{array}$ \\
\hline
\end{tabular}

(3) Walk $500 \mathrm{~m}$

\begin{tabular}{lllll}
\hline 1 & 2 & 3 & 4 & 5 \\
\hline Not at all & $\begin{array}{l}\text { A little of } \\
\text { the time }\end{array}$ & $\begin{array}{l}\text { Some of the } \\
\text { time }\end{array}$ & $\begin{array}{l}\text { Most of the } \\
\text { time }\end{array}$ & $\begin{array}{l}\text { All of the } \\
\text { time }\end{array}$ \\
\hline
\end{tabular}

(4) Are you reliant on walking aids?

\begin{tabular}{lllll}
\hline 1 & 2 & 3 & 4 & 5 \\
\hline Not at all & $\begin{array}{l}\text { A little of } \\
\text { the time }\end{array}$ & $\begin{array}{l}\text { Some of the } \\
\text { time }\end{array}$ & $\begin{array}{l}\text { Most of the } \\
\text { time }\end{array}$ & $\begin{array}{l}\text { All of the } \\
\text { time }\end{array}$ \\
\hline $\begin{array}{l}\text { (5) Does your leg feel stiff? } \\
2\end{array}$ & 3 & 4 & \\
\hline 1 & 2 & & 5 \\
\hline Not at all & $\begin{array}{l}\text { A little of } \\
\text { the time }\end{array}$ & $\begin{array}{l}\text { Some of the } \\
\text { time }\end{array}$ & $\begin{array}{l}\text { Most of the } \\
\text { time }\end{array}$ & $\begin{array}{l}\text { All of the } \\
\text { time }\end{array}$ \\
\hline
\end{tabular}

\section{Hygiene}

(1) How easy is it to wash unassisted?

\begin{tabular}{lllll}
\hline 1 & 2 & 3 & 4 & 5 \\
\hline $\begin{array}{l}\text { Without any } \\
\text { difficulty }\end{array}$ & $\begin{array}{l}\text { With a little } \\
\text { difficulty }\end{array}$ & $\begin{array}{l}\text { With some } \\
\text { difficulty }\end{array}$ & $\begin{array}{l}\text { With much } \\
\text { difficulty }\end{array}$ & $\begin{array}{l}\text { Unable to } \\
\text { do }\end{array}$ \\
\hline
\end{tabular}

(2) How easy is it to dress yourself unassisted?

\begin{tabular}{lllll}
\hline 1 & 2 & 3 & 4 & 5 \\
\hline Without any & With a little & With some & With much & Unable to \\
difficulty & difficulty & difficulty & difficulty & do \\
\hline
\end{tabular}




\section{Leisure}

(1) Have you been able to do as much physical recreation as you would like?

\begin{tabular}{lllll}
\hline 1 & 2 & 3 & 4 & 5 \\
\hline Not at all & $\begin{array}{l}\text { A little of } \\
\text { the time }\end{array}$ & $\begin{array}{l}\text { Some of the } \\
\text { time }\end{array}$ & $\begin{array}{l}\text { Most of the } \\
\text { time }\end{array}$ & $\begin{array}{l}\text { All of the } \\
\text { time }\end{array}$ \\
\hline
\end{tabular}

(2) Have you been able to do as many leisure activities such as seeing friends, hobbies etc as you would like?

\begin{tabular}{lllll}
\hline 1 & 2 & 3 & 4 & 5 \\
\hline Not at all & $\begin{array}{l}\text { A little of } \\
\text { the time }\end{array}$ & $\begin{array}{l}\text { Some of the } \\
\text { time }\end{array}$ & $\begin{array}{l}\text { Most of the } \\
\text { time }\end{array}$ & $\begin{array}{l}\text { All of the } \\
\text { time }\end{array}$ \\
\hline
\end{tabular}

\section{Work/Employment}

(1) How difficult is it to complete your normal work/household duties

\begin{tabular}{lllll}
\hline 1 & 2 & 3 & 4 & 5 \\
\hline $\begin{array}{l}\text { Without any } \\
\text { difficult }\end{array}$ & $\begin{array}{l}\text { With a little } \\
\text { difficulty }\end{array}$ & $\begin{array}{l}\text { With some } \\
\text { difficulty }\end{array}$ & $\begin{array}{l}\text { With much } \\
\text { difficulty }\end{array}$ & $\begin{array}{l}\text { Unable to } \\
\text { do }\end{array}$ \\
\hline
\end{tabular}

(2) To what extent have you had to make changes to your duties

\begin{tabular}{lllll}
\hline 1 & 2 & 3 & 4 & 5 \\
\hline $\begin{array}{l}\text { None of the } \\
\text { time }\end{array}$ & $\begin{array}{l}\text { A little of } \\
\text { the time }\end{array}$ & $\begin{array}{l}\text { Some of the } \\
\text { time }\end{array}$ & $\begin{array}{l}\text { Most of the } \\
\text { time }\end{array}$ & $\begin{array}{l}\text { All of the } \\
\text { time }\end{array}$ \\
\hline
\end{tabular}

\section{Planning}

(1) To what extent do you feel your whole life is "on hold"?

\begin{tabular}{lllll}
\hline 1 & 2 & 3 & 4 & 5 \\
\hline Not at all & $\begin{array}{l}\text { A little of } \\
\text { the time }\end{array}$ & $\begin{array}{l}\text { Some of the } \\
\text { time }\end{array}$ & $\begin{array}{l}\text { Most of the } \\
\text { time }\end{array}$ & $\begin{array}{l}\text { All of the } \\
\text { time }\end{array}$ \\
\hline
\end{tabular}

\section{Feelings and Emotions}

If you do too much in a day, to what extent does it affect what you do the next day

(1) Do you feel angry or frustrated about your situation?

\begin{tabular}{lllll}
\hline 1 & 2 & 3 & 4 & 5 \\
\hline Not at all & $\begin{array}{l}\text { A little of } \\
\text { the time }\end{array}$ & $\begin{array}{l}\text { Some of the } \\
\text { time }\end{array}$ & $\begin{array}{l}\text { Most of the } \\
\text { time }\end{array}$ & $\begin{array}{l}\text { All of the } \\
\text { time }\end{array}$ \\
\hline $\begin{array}{l}\text { (2) Do you feel less capable? } \\
2\end{array}$ & 3 & 4 & \\
\hline 1 & 2 & & 5 \\
\hline Not at all & $\begin{array}{l}\text { A little of } \\
\text { the time }\end{array}$ & $\begin{array}{l}\text { Some of the } \\
\text { time }\end{array}$ & $\begin{array}{l}\text { Most of the } \\
\text { time }\end{array}$ & $\begin{array}{l}\text { All of the } \\
\text { time }\end{array}$ \\
\hline
\end{tabular}

(3) Do you try and protect your limb?

\begin{tabular}{lllll}
\hline 1 & 2 & 3 & 4 & 5 \\
\hline Not at all & $\begin{array}{l}\text { A little of } \\
\text { the time }\end{array}$ & $\begin{array}{l}\text { Some of the } \\
\text { time }\end{array}$ & $\begin{array}{l}\text { Most of the } \\
\text { time }\end{array}$ & $\begin{array}{l}\text { All of the } \\
\text { time }\end{array}$ \\
\hline
\end{tabular}

(4) Do you feel you lose your temper easily?

\begin{tabular}{lllll}
\hline 1 & 2 & 3 & 4 & 5 \\
\hline Not at all & $\begin{array}{l}\text { A little of } \\
\text { the time }\end{array}$ & $\begin{array}{l}\text { Some of the } \\
\text { time }\end{array}$ & $\begin{array}{l}\text { Most of the } \\
\text { time }\end{array}$ & $\begin{array}{l}\text { All of the } \\
\text { time }\end{array}$ \\
\hline
\end{tabular}

(5) Do you feel depressed?

\begin{tabular}{lllll}
\hline 1 & 2 & 3 & 4 & 5 \\
\hline Not at all & $\begin{array}{l}\text { A little of } \\
\text { the time }\end{array}$ & $\begin{array}{l}\text { Some of the } \\
\text { time }\end{array}$ & $\begin{array}{l}\text { Most of the } \\
\text { time }\end{array}$ & $\begin{array}{l}\text { All of the } \\
\text { time }\end{array}$ \\
\hline
\end{tabular}

\section{Cosmetic}

(1) How happy are you with the appearance of your leg?

\begin{tabular}{llllll}
\hline 0 & 1 & 2 & 3 & 4 & 5 \\
\hline $\begin{array}{l}\text { Extremely } \\
\text { happy }\end{array}$ & & & & & $\begin{array}{l}\text { Extremely } \\
\text { unhappy }\end{array}$ \\
\hline
\end{tabular}

(2) How normal do you think your leg is?

\begin{tabular}{|c|c|c|c|c|c|}
\hline 0 & 1 & 2 & 3 & 4 & 5 \\
\hline Completely & & & & & Extremely \\
\hline normal & & & & & abnormal \\
\hline
\end{tabular}

\section{References}

1. Swiontkowski MF, Buckwalter JA, et al. The outcomes movement in orthopaedic surgery: where we are and where we should go. J Bone Joint Surg Am 1999;81(5):732-740. DOI: 10.2106/00004623$199905000-00016$.

2. Health Do. Guidance on the routine collection of Patient Reported Outcomes (PROMs). 2008.

3. Health Do. High Quality Care For All: NHS Next Stage Review Final Report. 2008.

4. Kim SJ, Balce GC, et al. Is bilateral lower limb lengthening appropriate for achondroplasia?: Midterm analysis of the complications and quality of life. Clin Orthop Relat Res 2012;470(2):616-621. DOI: 10.1007/ s11999-011-1983-y.

5. Paley D, Catagni MA, et al. Ilizarov treatment of tibial nonunions with bone loss. Clin Orthop Relat Res 1989;241:146-165. DOI: 10.1097/00003086-198904000-00017.

6. Modin M, Ramos T, et al. Postoperative impact of daily life after primary treatment of proximal/distal tibiafracture with Ilizarov external fixation. J Clin Nurs 2009;18(24):3498-3506. DOI: 10.1111/j.1365-2702.2009.02859.x.

7. Hrutkay JM, Eilert RE. Operative lengthening of the lower extremity and associated psychological aspects: the Children's Hospital experience. J Pediatr Orthop 1990;10(3):373-377. DOI: 10.1097/01241398-199005000-00015.

8. Fitzpatrick R, Davey C, et al. Evaluating patient-based outcome measures for use in clinical trials. Health Technol Assess 1998;2(14):174.

9. Mokkink LB, Terwee CB, et al. The COSMIN checklist for assessing the methodological quality of studies on measurement properties of health status measurement instruments: an international Delphi study. Qual Life Res 2010;19(4):539-549. DOI: 10.1007/s11136-0109606-8.

10. Stewart AL, Hays RD, et al. The MOS short-form general health survey. Reliability and validity in a patient population. Med Care 1988;26(7):724-735. DOI: 10.1097/00005650-198807000-00007.

11. Tarlov AR, Ware Jr., JE, et al. The Medical Outcomes Study. An application of methods for monitoring the results of medical care. JAMA 1989;262(7):925-930. DOI: 10.1001/jama.1989. 03430070073033.

12. Burton M, Walters SJ, et al. An evaluation of patient-reported outcome measures in lower limb reconstruction surgery. Qual Life Res 2012;21(10):1731-1743. DOI: 10.1007/s11136-011-0090-6. 
13. Obremskey WT, Brown O, et al. Comparison of SF-36 and Short Musculoskeletal Functional Assessment in recovery from fixation of unstable ankle fractures. Orthopedics 2007;30(2):145-151.

14. Bowden G, McNally M, et al. Limb salvage vs amputation. Oxford Handbook of Orthopaedics and Trauma. Oxford University Press, 2010.

15. Ebrahim S, Barer D, et al. Use of the Nottingham Health Profile with patients after a stroke. J Epidemiol Community Health 1986;40(2):166-169. DOI: 10.1136/jech.40.2.166.

16. Garellick G, Malchau H, et al. Specific or general health outcome measures in the evaluation of total hip replacement. A comparison between the Harris hip score and the Nottingham Health Profile. J Bone Joint Surg Br 1998;80(4):600-606. DOI: 10.1302/0301-620X.80B4.8345.

17. Garcia P, McCarthy M. Measuring health. A step in the development of city health profiles Copenhagen: World Health Organization Regional Office for Europe. 1995.

18. Hunt SM, McKenna SP, et al. The Nottingham Health Profile: subjective health status and medical consultations. Soc Sci Med A 1981; 15(3 Pt 1):221-229. DOI: 10.1016/0271-7123(81)90005-5.

19. Landry GJ. Functional outcome of critical limb ischemia. J Vasc Surg 2007;45(6):A141-A148. DOI: 10.1016/j.jvs.2007.02.052.

20. Eisen M, Ware Jr JE, et al. Measuring components of children's health status. Medical care 1979;17(9):902-921. DOI: 10.1097/00005650197909000-00003.

21. Brinker MR, Trivedi A, et al. The Debilitating Effects of Femoral Nonunion on Health-Related Quality of Life. J Orthop Trauma 2017 Feb;31(2):e37-e42.

22. Mancuso CA, Jout J, et al. Fulfillment of patients' expectations for total hip arthroplasty. J Bone Joint Surg Am 2009;91(9):2073-2078. DOI: 10.2106/JBJS.H.01802.

23. Brinker MR, Hanus BD, et al. The devastating effects of tibial nonunion on health-related quality of life. J Bone Joint Surg Am 2013;95(24):2170-2176. DOI: 10.2106/JBJS.L.00803.

24. Riskowski JL, Hagedorn TJ, et al. Measures of foot function, foot health, and foot pain: American Academy of Orthopedic Surgeons Lower Limb Outcomes Assessment: Foot and Ankle Module (AAOSFAM), Bristol Foot Score (BFS), Revised Foot Function Index (FFI-R), Foot Health Status Questionnaire (FHSQ), Manchester Foot Pain and Disability Index (MFPDI), Podiatric Health Questionnaire (PHQ), and Rowan Foot Pain Assessment (ROFPAQ). Arthritis Care Res (Hoboken) 2011;63(Suppl 11):S229-S239. DOI: 10.1002/acr.20554.

25. Johanson NA, Liang MH, et al. American Academy of Orthopaedic Surgeons lower limb outcomes assessment instruments. Reliability, validity, and sensitivity to change. J Bone Joint Surg Am 2004;86(5):902-909. DOI: 10.2106/00004623-200405000-00003.

26. Martin DP, Engelberg R, et al. Development of a musculoskeletal extremity health status instrument: the Musculoskeletal Function Assessment instrument. J Orthop Res 1996;14(2):173-181. DOI: 10.1002/jor.1100140203.

27. Engelberg R, Martin DP, et al. Musculoskeletal Function Assessment instrument: criterion and construct validity. J Orthop Res 1996;14(2):182-192. DOI: 10.1002/jor.1100140204.

28. Vallier HA, Cureton BA, et al. Factors influencing functional outcomes after distal tibia shaft fractures. J Orthop Trauma 2012;26(3):178-183. DOI: 10.1097/BOT.0b013e31823924df.
29. Harris AM, Patterson BM, et al. Results and outcomes after operative treatment of high-energy tibial plafond fractures. Foot Ankle Int 2006;27(4):256-265. DOI: 10.1177/107110070602700406.

30. Bowden G, McNally M, et al. Measurement of outcome in orthopedic trauma. Oxford Handbook of Orthopaedics and Trauma. Oxford University Press, 2010.

31. Jaglal S, Lakhani Z, et al. Reliability, validity, and responsiveness of the lower extremity measure for patients with a hip fracture.J Bone Joint Surg Am 2000;82-A(7):955-962. DOI: 10.2106/00004623-200007000-00007.

32. Foster PA, Barton SB, et al. The treatment of complex tibial shaft fractures by the llizarov method. J Bone Joint Surg $\mathrm{Br}$ 2012;94(12):1678-1683. DOI: 10.1302/0301-620X.94B12.29266.

33. Tegner $Y$, Lysholm J. Rating systems in the evaluation of knee ligament injuries. Clin Orthop Relat Res 1985;198:43-49. DOI: 10.1097/00003086-198509000-00007.

34. Barker KL, Lamb SE, et al. Functional recovery in patients with nonunion treated with the llizarov technique. J Bone Joint Surg $\mathrm{Br}$ 2004 Jan;86(1):81-85.

35. Brinker MR, O'Connor DP. Outcomes of tibial nonunion in older adults following treatment using the llizarov method. J Orthop Trauma 2007 Oct;21(9):634-642.

36. Ghoneem HF, Wright JG, et al. The llizarov method for correction of complex deformities. Psychological and functional outcomes.J Bone Joint Surg Am 1996 Oct;78(10):1480-1485.

37. Gunes T, Erdem M, et al. Quality of life in patients with varus gonarthrosis treated with high tibial osteotomy using the circular external fixator. Knee Surg Sports Traumatol Arthrosc 2008 Mar;16(3):311-316. DOI: 10.1007/s00167-007-0473-y. Epub 2008 Jan 9.

38. Horn DM, Fragomen AT, et al. Supramalleolar osteotomy using circular external fixation with six-axis deformity correction of the distal tibia. Foot Ankle Int 2011 Oct;32(10):986-993.

39. Robinson PM, Papanna MC, et al. High tibial osteotomy in medial compartment osteoarthritis and varus deformity using the Taylor spatial frame: early results. Strategies Trauma Limb Reconstr. 2011 Nov;6(3):137-145.

40. McKee $M D$, Yoo $D$, et al. Health status after Ilizarov reconstruction of post-traumatic lower-limb deformity. J Bone Joint Surg Br 1998 Mar;80(2):360-364.

41. Mekhail AO, Abraham E, et al. Bone transport in the management of posttraumatic bone defects in the lower extremity. J Trauma 2004 Feb;56(2):368-378.

42. Ramos T, Ekholm C, et al. The Ilizarov external fixator-a useful alternative for the treatment of proximal tibial fractures. A prospective observational study of 30 consecutive patients. BMC Musculoskelet Disord 2013 Jan 7;14:11.

43. Rozbruch SR, Pugsley JS, et al. Repair of tibial nonunions and bone defects with the Taylor Spatial Frame. J Orthop Trauma 2008 Feb;22(2):88-95.

44. Spiegl U, Pätzold R, et al. Clinical course, complication rate and outcome of segmental resection and distraction osteogenesis after chronic tibial osteitis. Injury 2013 Aug;44(8):1049-1056.

45. Tellisi N, Fragomen AT, et al. Joint preservation of the osteoarthritic ankle using distraction arthroplasty. Foot Ankle Int 2009 Apr;30(4):318-325. 